\title{
Volleyball Athlete Character Study
}

\author{
Aryadie Adnan ${ }^{1 *}$ and Arialdi Dafit ${ }^{2}$
}

\author{
${ }^{1,2}$ Dep. of Coaching, Faculty of Sport Science, Universitas Negeri Padang, Padang, Indonesia \\ *Corresponding author. Email: aryadie.adnan@fik.unp.ac.id
}

\begin{abstract}
The problem in this study is the low performance of volleyball athletes and according to the trainer, the athletes do not yet fully possess the characteristics that support achievement. This study aims to determine the character of BBS Lima Puluh Kota volleyball athletes. This research is a descriptive study with the aim of describing the characteristics of BBS volleyball athletes in accordance with the factual. Data collected are primary and secondary data. Primary data were obtained from questionnaire instruments and secondary data were obtained from documentation. The sampling technique in this study is the total sampling with a total sample of 30 people. The result study showed thatthe character values possessed by BBS volleyball athletes are good and very good. Each percentage of BBS volleyball athlete character is $50 \%$. This means that 15 BBS volleyball athletes have good character scores and 15 people are of very good character. Based on these results it can be concluded that the low performance of volleyball athletes is not because athletes do not yet have the characteristics to support achievement.
\end{abstract}

Keywords: Character, athlete, volleyball

\section{INTRODUCTION}

Each person's character is born with strength or mental and moral qualities by reflecting one's overall personality and playing a guiding role in the future. Self character for someone from mind (way of thinking), because the mind will influence or determine the words, actions or behavior and how to respond or respond to and assess things, and develop into habits. These repetitive habits eventually form the character in the individual that characterizes his personality. Soedarsono (2009) states that:

Character is a collection of values manifested in a system of impulse that underlies attitudes and behavior, which is displayed steadily. Collection of values formed in a person through education, experience, experiments, sacrifice and environmental influences, become an intrinsic value that underlies attitudes and behaviors, so that characters do not come naturally, so characters are grown and developed.

The most important element in character formation is the mind, because in it there are all programs that are formed from life experience, are the rapporteur of everything. Thinking is a mental activity that involves the work of the brain. Thinking activities involve the human person and also involve human feelings and desires. Thinking about something means directing oneself at a particular object, being aware of its presence actively presenting in the mind the doubting activity, designing, ascertaining, calculating, measuring, evaluating, comparing, classifying, distinguishing, connecting, interpreting, analyzing and analyzing, reasoning or drawing conclusions, and decide (Sobbur 2003).

Yaumi (2014) describes each character value accompanied by a simple indicator formulation, namely religious, honest, tolerance, discipline, hard work, creative, independent, democratic, rewarding achievement, friendly / communicative, responsibility. Character occupies a mental component in the four components of volleyball sports performance. To be able to improve the performance or performance of volleyball, an athlete needs to have a strong mentality, so that he can train and compete in high spirits, be fully approached, never give up and not easily be disturbed by his personal problems. Thus he can carry out the training program seriously, so that he can get the maximum physical, high techniques and appropriate competition strategies, according to the training program designed by his trainer. Awkward mentality doesn't come on its own. The education and training of the coach is one of the factors influencing the character of the volleyball athlete

Found mostly on the volleyball court in West Sumatra, the trainers in designing an exercise program and its implementation, put more emphasis on the physical, technical and tactical aspects. While for the mental aspects of the trainer to disguise it, it means that in this case individual principles in training on the mental aspects are ignored. Yet every human being born has a mental (character) that is different from each 
other. It takes a good physical in the competition so that you will not feel significant fatigue. Athletes are also required to be skilled at mastering the correct techniques in volleyball games. To support the achievement, it is very important that the athlete has a positive character in other words, the champion mentality, and the coach must also know the character that is in his students. In this case, stated Om Dam in Setyobroto (2001) which states that "approximately $90 \%$ of an athlete's success is influenced by his mental condition". The positive character possessed by the athlete as well as the knowledge will be adjusted to the character in the process of training the sport, also the match by the coach will determine the way of coaching in training. This includes completing knowledge of athlete attitudes and preferences, appropriate training styles, motivation, as well as how to create an ideal environment for athletes by coaches, so as to influence athlete's behavior and attitudes during the training process and dealing with matches. Thus also affect the achievement of his achievements.

Based on the results of interviews with coaches volleyball BBS, athletes volleyball BBS not yet fully have the characteristics that support achievement, where the athletes have not applied disipliner, work hard in practice, emotional still cannot these athletes hang or still unstable, believing himself in matches who is still low and creative to make decisions when in the game. Moreover in the case of athletes competing in the klub volleyball BBS has never won a championship in a match, because not all athletes in $\mathrm{k}$ lub BBS volleyball athletes who excel or have much experience in the game of volleyball. The formulation of the problem in this study is how the character of BBS volleyball athletes.

\section{RESEARCH METHODS}

This research is a descriptive study that aims to describe or describe the events that occur. According to Sugiyono (2014: 147) descriptive method is a method used to describe or analyze a research result but is not used to make conclusions that are generally accepted or generalized. Research conducted in the field volley ballKenagarian BBS Stone Balang $\mathrm{k}$ ec observations Harau k abupaten Fifty Cities. The implementation is on the fourth week of April 2019, namely on Sunday, April 28, 2019 and on Tuesday, April 30, 2019.

The population in this study were all BBS volleyball athletes, NagariBatuBalang, Harau District, Lima Puluh Kota District, as many as 30 people. The sampling technique in this research is to use the total sampling, $m$ aka the number of samples d nature of this study were 30 . The instrument used in this study was a questionnaire or questionnaire. The questionnaire used contained written statements, so that in filling out the questionnaire, respondents gave a checklist in the column provided and the answers were appropriate. The questionnaire used was a Likert modification. The answers to each instrument item that uses a Likert scale have gradations from very positive to very negative and are scored. Questionnaire that has been compiled, then tested the validity of aspects of the material, construction, and language. Validity is done by asking competent judgment and experience in the field of character science. In this case the acting as validator is Prof. Dr. Mudjiran, MS, Kons., lecturer at the Guidance and Counseling Department, Faculty of Education, Padang State University. Upon validation of the implemented and obtained advice, the results of va 1 idasi used as the basis for the revised questionnaires. Questionnaire is suitable for use after a revision.

On the advice of the validator, the questionnaire which initially amounted to 62 statements became 59 statements by changing a few sentences on the items of the questionnaire statement. Next, the questionnaire instrument was tested on AMKOR volleyball athletes. This trial is conducted to find out whether the instrument meets the requirements of a good instrument or not. After the questionnaire instrument was tested, empirical validity was carried out. Empirical validity is validity that is reviewed with certain criteria. This criterion is used to determine the high and low validity coefficients of evaluation tools made through product moment correlation calculations.

The results of the calculation of the reliability of the instrument obtained the reliability coefficient of the questionnaire instrument the athlete's character value is 0.989 which indicates a very high level of reliability, meaning that the questionnaire fulfills adequate characteristics to be used in research. The steps of data collection undertaken in this study are visiting the research location, distributing questionnaires to research subjects, collecting questionnaires that have been filled out by athletes, processing data and analyzing data, and making conclusions and recommendations of research results. There are two techniques of data collection research results obtained, namely quantitative data and qualitative data.

Analysis of the research data obtained is then presented in the form of a categorization table. In this study, the categorization given is Very Good (SB), Good (B), Medium (S), Poor (K), Very Poor (SK). Data grouping is done by determining the range of scores, class length, and many classes. According to Furqon (2013) determining the range, class length, and many classes is as follows:

1.Range $(\mathrm{R})=$ Highest score - lowest score

2.Length of class $(p)=1+3.3 \log n$

3. Many classes $(b k)=R: p$ 


\section{RESULTS AND DISCUSSION}

Based on the research results of $30 \mathrm{BBS}$ volleyball athletes, the average value of BBS volleyball athletes is
188.6, the minimum value of BBS volleyball athletes is 158 and the maximum value of BBS volleyball athletes is 204. The data can be seen in the table below this.

Table 1 . Average Character Rating of BBS Volleyball Athletes

\begin{tabular}{|c|c|c|c|c|}
\hline Variable & The mean & Min & Max & N \\
\hline Value of BBS Volleyball Athletes & 188,6 & 158 & 204 & 30 \\
\hline
\end{tabular}

From the results of the study, a description of the categorization and percentage of BBS volleyball athlete character values was obtained from very good and good. The categorization of BBS volleyball athlete character values can be seen in the table below:

Table 2. Category Values of BBS Volleyball Athletes

\begin{tabular}{|c|c|c|l|}
\hline Score Interval & amount & Percentage (\%) & \multicolumn{1}{|c|}{ Category } \\
\hline $56-89$ & 0 & 0 & Very less \\
\hline $90-123$ & 0 & 0 & Less \\
\hline $124-157$ & 0 & 0 & Is \\
\hline $158-191$ & 15 & 50 & Well \\
\hline $192-225$ & 15 & 50 & Very good \\
\hline Total & 30 & & \\
\hline
\end{tabular}

From the table above it can be seen that the character score of the BBS volleyball athlete in the excellent category is 15 people, in the good category there are 15 athletes, while there are no athletes in the moderate, poor and very less categories.

The highest value of the character values of 30 BBS volleyball athletes was 204. that is 1 person. Then 4 people have a value of 202,1 person with a value of 201,1 person 200,1 person a value of 198,3 people a value of 196, 2 people with a value of 195,1 person with a value of 194, 1 person a value of 192,1 person a value of 190, 1-person value 189. Furthermore, the value of 188 is 1 person, 187 is 1 person, 182 is 1 person, 180 is 1 person, 179 is 2 people, 177 is 1 person, 174 is 1 person, 172 is 1 person, 171 is 1 person, 167 are 1 person, and 158 are 1 person.

From the BBS volleyball athlete's character values, the same value that most volleyball athletes have is a character score of 202, which is 4 people, then 196 of 3 people, 195 and 190 respectively 2 people. While 19 other people have different values. In general, the results of the volleyball athlete character values show different values because each athlete has a different character.

\section{Achievement Value -Value Character Volleyball Athletes BBS \\ 1. Religious}

The athlete's religious value is measured from 7 item questionnaire statements. From the results of 30 respondents, a minimum score of 15 and a maximum score of 26 were obtained. The average religious value of BBS volleyball athletes was 20.8. The categorization and percentage of religious values of BBS volleyball athletes can be seen in the table below:

Table 3 . The Religious Value Category for Volleyball Athletes BBS

\begin{tabular}{|c|c|c|c|c|}
\hline No & Score Interval & amount & Percentage (\%) & Category \\
\hline 1 & $7-11$ & 0 & 0.0 & Very less \\
\hline 2 & $12-16$ & 4 & 13.3 & Less \\
\hline 3 & $17-21$ & 14 & 46.7 & Is \\
\hline 4 & $22-26$ & 12 & 40.0 & Well \\
\hline 5 & $27-31$ & 0 & 0.0 & Very good \\
\hline \multicolumn{2}{|r|}{ Total } & 30 & 100 & \\
\hline
\end{tabular}

From the table above it can be seen that there are no athletes who are in the very good and very less categories. Athletes in the good category numbered 12 people, the moderate or enough category were 14 people 
, and the religious value for the category of less than 4 people. The percentage of religious values of athletes from the largest to the smallest is in the medium category, namely $46.7 \%$, $40 \%$ good category, $13.3 \%$ less category, very less and very good category $0 \%$.

\section{Honest}

The honest character value of BBS volleyball athletes was measured from 6 questionnaire statements. From the results of 30 respondents, a minimum score of 14 was obtained and a maximum score of 23 . The average honest character of BBS volleyball athletes was 19.5. The categorization and percentage of honesty values for BBS volleyball athletes can be seen in the table below:

Table 4 . Honorary Value Category for Volleyball Athletes BBS

\begin{tabular}{|c|c|c|c|c|}
\hline No & Score Interval & amount & Percentage (\%) & Category \\
\hline 1 & $6-9$ & 0 & 0.0 & Very less \\
\hline 2 & $10-13$ & 0 & 0.0 & Less \\
\hline 3 & $14-17$ & 4 & 13.3 & Is \\
\hline 4 & $18-21$ & 19 & 63.3 & Well \\
\hline 5 & $22-25$ & 7 & 23.3 & Very good \\
\hline & Total & 30 & 100 & \\
\hline
\end{tabular}

From the table above it can be seen that the number of athletes who score very good honesty is 7 people with a percentage of $23.3 \%$, a good category numbering 19 people with a percentage of $63.3 \%$, a moderate category or enough amounting to 4 people with a percentage of $13.3 \%$, not there are athletes who value honesty in the category of less and very less .

\section{Tolerance}

The tolerance value of BBS volleyball athletes is measured from a questionnaire which amounts to 5 statements. From the results of 30 respondents, a minimum score of 13 was obtained and a maximum score of 20. The average tolerance of BBS volleyball athletes was 16.7. The categorization and percentage of tolerance values for BBS volleyball athletes can be seen in the table below:

Table 5 . Tolerance Value Category for Volleyball Athletes BBS

\begin{tabular}{|c|c|c|c|l|}
\hline No & Score Interval & amount & Percentage (\%) & \multicolumn{1}{|c|}{ Category } \\
\hline 1 & $4-7$ & 0 & 0.0 & Very less \\
\hline 2 & $8-11$ & 0 & 0.0 & Less \\
\hline 3 & $12-15$ & 8 & 26.7 & Is \\
\hline 4 & $16-19$ & 20 & 66.7 & Well \\
\hline 5 & $20-23$ & 2 & 6.7 & Very good \\
\hline \multicolumn{2}{|c|}{ Total } & 30 & 100 & \\
\hline
\end{tabular}

From the table above it can be seen that the number of athletes with excellent tolerance values is 2 people with a percentage of $6.7 \%$, a good category totaling 20 people with a percentage of $66.7 \%$, a moderate category or enough amounting to 8 people with a percentage of $26.7 \%$, a category less and very less number of 0 people.

\section{Discipline}

The discipline value of BBS volleyball athletes is measured from a questionnaire of 6 statements. From the results of 30 respondents, a minimum score of 18 and a maximum score of 24 were obtained. The average discipline of BBS volleyball athletes was 21.1. The categorization and percentage of discipline values for BBS volleyball athletes can be seen in the table below:

Table 6 . The Volleyball Athletes BBS Disciplinary Value Category

\begin{tabular}{|c|c|c|c|c|}
\hline No & Score Interval & amount & Percentage (\%) & Category \\
\hline 1 & $6-9$ & 0 & 0.0 & Very less \\
\hline 2 & $10-13$ & 0 & 0.0 & Less \\
\hline 3 & $14-17$ & 0 & 0.0 & Is \\
\hline 4 & $18-21$ & 17 & 56.7 & Well \\
\hline 5 & $22-25$ & 13 & 43.3 & Very good \\
\hline \multicolumn{2}{|r|}{ Total } & 30 & 100 & \\
\hline
\end{tabular}

From the table above it can be seen that there are no athletes whose disciplinary value is in the category of very less, less, and moderate. The number of athletes whose disciplinary grades are good is 17 people with a percentage of $56.7 \%$ and very good categories is 13 people with a percentage of $43.3 \%$. 


\section{Hard work}

The value of BBS volleyball athlete's hard work is measured from a questionnaire of 4 statements. From the results of 30 respondents, obtained a minimum score of 8 and a maximum value of 16. The average hard work of BBS volleyball athletes was 12.83. The categorization and percentage of the hard work value of BBS volleyball athletes can be seen in the table below:

Table 7 . The category of Hard Work Value for Volleyball Athlete BBS

\begin{tabular}{|c|c|c|c|c|}
\hline No & Score Interval & Amount & Percentage (\%) & Category \\
\hline 1 & $4-6$ & 0 & 0.0 & Very less \\
\hline 2 & $7-9$ & 1 & 3,3 & Less \\
\hline 3 & $10-12$ & 12 & 40.0 & Is \\
\hline 4 & $13-15$ & 14 & 46.7 & Well \\
\hline 5 & 16-18 & 3 & 10.0 & Very good \\
\hline \multicolumn{2}{|r|}{ Total } & 30 & 100 & \\
\hline
\end{tabular}

From the table above it can be seen that the number of athletes who score very good hard work is 3 people, the good category is 6 people, the moderate category is 16 people enough, the category is less than 3 people, and the value of hard work the category is very less numbered 2 people. The percentage of hard work value of BBS volleyball athletes in the excellent category is $10 \%$, in the good category is $46.7 \%$, the medium category is $40 \%$, the category is less and very less $0 \%$.

Table 8 . The Value Category of Creativity in Volleyball Athletes BBS

\begin{tabular}{|c|c|c|c|c|}
\hline No & Score Interval & amount & Percentage (\%) & Category \\
\hline 1 & $3-4$ & 0 & 0.0 & Very less \\
\hline 2 & $5-6$ & 0 & 0.0 & Less \\
\hline 3 & $7-8$ & 10 & 33.3 & Is \\
\hline 4 & $9-10$ & 13 & 43.3 & Well \\
\hline 5 & $11-12$ & 7 & 23.3 & Very good \\
\hline \multicolumn{2}{|c}{} \\
\hline
\end{tabular}

From the table above it can be seen that the number of athletes whose creativity is categorized as excellent is 7 people, the good category is 13 people, the moderate category is 10 people. There are no athletes whose creativity is in the category of less and very less. the percentage of the creativity value of the BBS volleyball athlete in the excellent category was $23.3 \%$, the good category was $43.3 \%$, the moderate category was $33.3 \%$, the category was poor and very less $0 \%$.

7. Mandiri

The independence of BBS volleyball athletes is measured from a questionnaire which amounts to 5 statements. From the results of 30 respondents, obtained a minimum score of 12 and a maximum value of 20 . The average independent value of BBS volleyball athletes was 17.23. The categorization and percentage of independent values for BBS volleyball athletes can be seen in the table below:

diri Volleyball Athletes BBS

\begin{tabular}{|c|c|c|c|c|}
\hline No & Score Interval & amount & Percentage (\%) & Category \\
\hline 1 & $4-7$ & 0 & 0.0 & Very less \\
\hline 2 & $8-11$ & 0 & 0.0 & Less \\
\hline 3 & $12-15$ & 7 & 23.3 & Is \\
\hline 4 & $16-19$ & 15 & 50.0 & Well \\
\hline 5 & $20-23$ & 8 & 26.7 & Very good \\
\hline \multicolumn{2}{|c}{} \\
\hline
\end{tabular}

From the table above, it can be seen that there are no BBS volleyball athletes whose value of independence is lacking and very poor. The number of athletes who have independence in the medium category is 7 people, the good category is 15 people, and the very good category is 8 people. The percentage of independent value of BBS volleyball athletes in the very good category was $26.7 \%$, the good category was $50 \%$, 
the moderate category was $23.3 \%$, the category was poor and very less $0 \%$.

\section{Democratic}

The democratic value of BBS volleyball athletes is measured from a questionnaire of 4 statements. From the results of 30 respondents, obtained a minimum score of 10 and a maximum value of 16 . The average democratic value of BBS volleyball athletes was 13.63. The categorization and percentage of democratic values of BBS volleyball athletes can be seen in the table below:

Table 10. The Democratic Values Category for Volleyball Athletes BBS

\begin{tabular}{|c|c|c|c|c|}
\hline No & Score Interval & amount & Percentage (\%) & Category \\
\hline 1 & $4-6$ & 0 & 0.0 & Very less \\
\hline 2 & $7-9$ & 0 & 0.0 & Less \\
\hline 3 & $10-12$ & 9 & 30.0 & Is \\
\hline 4 & $13-15$ & 12 & 40.0 & Well \\
\hline 5 & $16-18$ & 9 & 30.0 & Very good \\
\hline \multicolumn{2}{|c}{} \\
\hline
\end{tabular}

From the table above it can be seen that there are no BBS volleyball athletes whose democratic values are categorized as lacking or lacking. The number of athletes who have democratic values in the medium category is 9 people, the good category is 12 people, the very good category is 9 people. The percentage of democratic scores of BBS volleyball athletes in the excellent category is $30 \%$, the good category is $40 \%$, the moderate category is $30 \%$, the category of lack and very less is $0 \%$

\section{Appreciate Achievement}

The value of appreciating the achievements of BBS volleyball athletes is measured from a questionnaire of 5 statements. From the results of 30 respondents, obtained a minimum score of 15 and a maximum value of 20 . The average value of appreciating the achievements of BBS volleyball athletes was 18.97. The categorization and percentage of values that value the achievements of BBS volleyball athletes can be seen in the table below:

Table 11. The Value Category Appreciates the Achievements of BBS Volleyball Athletes

\begin{tabular}{|c|c|c|c|c|}
\hline No & Score Interval & amount & Percentage (\%) & Category \\
\hline 1 & $4-7$ & 0 & 0.0 & Very less \\
\hline 2 & $8-11$ & 0 & 0.0 & Less \\
\hline 3 & $12-15$ & 2 & 6.7 & Is \\
\hline 4 & $16-19$ & 14 & 46.7 & Well \\
\hline 5 & $20-23$ & 14 & 46.7 & Very good \\
\hline \multicolumn{2}{|c|}{ Total } & 30 & 100 & \\
\hline
\end{tabular}

From the table above it can be seen that there are no BBS volleyball athletes who value their achievements categorized as very less and less. The number of athletes who have a value of appreciating the achievements of the medium category is 2 people, the good category is 14 people, and the very good category is 14 people.

\section{Friendly / Communicative}

Friendly / communicative character of BBS volleyball athletes is measured from a questionnaire of 5 statements. From the results of 30 respondents, obtained a minimum score of 13 and a maximum value of 20 . The average value of friendly / communicative BBS volleyball athletes was 17.23 . The categorization and percentage of friendly / communicative characters of BBS volleyball athletes can be seen in the table below:

Table 12 . Friendly / Communicative Value Categories of BBS Volleyball Athletes

\begin{tabular}{|c|c|c|c|c|}
\hline No & Score Interval & amount & Percentage $(\%)$ & Category \\
\hline 1 & $4-7$ & 0 & 0.0 & Very less \\
\hline 2 & $8-11$ & 0 & 0.0 & Less \\
\hline 3 & $12-15$ & 7 & 23.3 & Is \\
\hline 4 & 16-19 & 17 & 56.7 & Well \\
\hline 5 & $20-23$ & 6 & 20.0 & Very good \\
\hline \multicolumn{2}{|r|}{ Total } & 30 & 100 & \\
\hline
\end{tabular}


From the table above it can be seen that there are no BBS volleyball athletes whose friendly / communicative value is in the category of very insufficient and insufficient. The number of athletes who have a friendly / communicative value in the medium category is 7 people, the good category is 17 people, and the very good category is 6 people.
The value of BBS volleyball athlete responsibility is measured from a questionnaire which amounts to 6 statements. From the results of 30 respondents, a minimum score of 14 and a maximum score of 24 were obtained. The average value of BBS volleyball athlete creativity was 21.3. The categorization and percentage of responsibility value of BBS volleyball athletes can be seen in the table below:

\section{Responsible}

Table 13. Value Categories Responsibilities of Volleyball Athletes BBS

\begin{tabular}{|c|c|c|l|}
\hline Score Interval & amount & Percentage $(\%)$ & \multicolumn{1}{|c|}{ Category } \\
\hline $6-9$ & 0 & 0.0 & Very less \\
\hline $10-13$ & 0 & 0.0 & Less \\
\hline $14-17$ & 3 & 10.0 & Is \\
\hline $18-21$ & 15 & 50.0 & Well \\
\hline $22-25$ & 12 & 40.0 & Very good \\
\hline Total & 30 & 100.0 & \\
\hline
\end{tabular}

From the table above it can be seen that there are no BBS volleyball athletes whose responsibilities are categorized as very less and less. The number of athletes who have a very good category of responsibility is 12 people, the good category is 15 people, and the medium category is 3 people.

\section{Discussion}

Based on the results of the research the character value of BBS volleyball athletes, the highest percentage obtained is $50 \%$ in the good category and $50 \%$ in the very good category. This means that some BBS volleyball athletes have good character and some have very good character in sports, especially volleyball sports, namely 15 people with good character and 15 people with very good character. This shows that the character of each volleyball athlete is different, but when categorized, the categories are only in the good and very good categories.

The character value of each athlete must be different, depending on the attitude, behavior and deeds done. These attitudes, behaviors and actions are reflected in religious values, honesty, tolerance, discipline, hard work, creative, democratic, independent, respect for achievement, friendship / communicative, and responsibility. An athlete with character if his attitude, behavior and actions are seen as in accordance with social norms prevailing in society. Instead the athlete is said to be characterless or very lacking in character if his actions are not in line with community norms. This is in line with the opinion of Suryabrata (2003: 3) which says that people are said to have no character or character if their attitudes, behavior, and actions are seen to be contrary to prevailing social values.

According to Coubertin (in Nucci, 2014: 726) through sports a better human being will be created, sport is considered capable of building character. Therefore, it is expected that BBS volleyball athletes have better character values than their non-athlete friends. The results showed that the BBS volleyball athlete's character values were good and very good, which meant that they could have better character values than non-athlete friends.

BBS volleyball athletes are students or students who also get character education at school. Lickona (2012: 54) says that the basis of a curriculum that contains character values and is integrated in subjects that will be taught to students or students in the hope of providing measurable direction and process in shaping the student's personality as a whole.

By having good character values and very good athletes are expected to have perseverance, self-control, problem solving, courage, and responsibility. According to Bredemeier (in Nucci, 2014: 727) the character values of a sportsman are able to control desires, have moral values, sportsmanship, creativity in the game, good cooperation within the team. The character values seen in this study are religious, honesty, tolerance, discipline, hard work, creativity, independence, democracy, respect for achievement, friendship / communication, and responsibility. From these character values, the highest percentage obtained in the excellent category is $46.7 \%$ in the value of appreciating achievement. Character values that have the highest percentage are in the good category, which are tolerant 
values, amounting to $66.7 \%$. The highest percentage of categories in the value of honesty, discipline, hard work, creative, democratic, independent, friendly, responsibility is good.

These character values are the values needed in a match to achieve a victory. According to Shields (in Nucci, 2014: 735) to assess the strength of the team, norms within the team are needed to reduce cheating or aggressive action. Therefore, the volleyball athlete must have the value of tolerance character and appreciate good achievements in a match and have the value of independence, hard work, creative, and honest who are good to create a conducive match.

The highest percentage of medium category is $46.7 \% \%$ on religious value, meaning that BBS volleyball athletes must further enhance the character of religious value to perfect the good character of an athlete, especially volleyball athletes. Given the highest religious value of athletes in the medium category, support and teaching from parents, coaches and the community are needed to improve the religious character of BBS volleyball athletes.

\section{CONCLUSIONS AND SUGGESTIONS}

Based on the results analysis and discussion of the research that has been described previously, it can be concluded from this study that the character values possessed by BBS volleyball athletes are in the good and very good categories. Each percentage is $50 \%$. This means that 15 BBS volleyball athletes have good character values, and another 15 people have very good character. The average BBS volleyball athlete character value is 188.6. The minimum value of BBS volleyball athlete's character is 158 and the maximum value of BBS volleyball athlete's character value is 204 .

\section{REFERENCES}

[1] Arikunto, Suharsimi. (1990). Research Management. Jakarta. RinekaCipta.

[2] Azwar, Syarifudin. (2009). Research method Jakarta: Student Library.

[3]Bennis,Diana,(http://democreducation.org/indek.php/ $\mathrm{f}$ eatures/what-is-democratic-education . Accessed Sept ember 25, 2018)

[4] Education Dutap. (2018). http://www.dutapenduk asi.com/ permendikbud-number-20-tahun-2018about-pow ering-ducation-characteristics. Accessed Novem ber 20, 2018 )

[5] Gunawan (2009) .http://kolleksi-skripsi.com , Accessed April 20, 2018)
[6] Gunawan, Adi. (2004). Born To Bea A Genius. Jakarta: Gramedia Main Library.

[7] Arifin, Z. (2013). Learning evaluation. Bandung: Rosda.

[8] Lickona, Thomas. (2012). Educating For Character: Educating to Shape Characters. Translation by Juma Abdu Wamaungo. Jakarta: Earth Literacy

[9] Litture, Florence. (1996). Personality Plus. Subtitles by Anton Adiwiyoto. Jakarta: BinarupaAksana.

[10] Nucci, P. Larry \&Darcia Narvaez. (2014). Moral and Character Education Handbook. Translation by Imam Baehaqie. Bandung: Nusa Media.

[11] Rajeev.http://www.buzzle.com/articles/zone-ofproxim al-development.html. (Accessed 25 September 2018 )

[12] Rosintaunesa. (2012). http://rosintaunesa.blogspot.co $\mathrm{m} / 20$ 12/01/intrumen-and-data-collectiontechniques.ht $\mathrm{ml} ? \mathrm{~m}=1$. Accessed September 26, 2018

[13] Sadewo, Ayu A. (2009). Ease of Educating Children: Character and Talent Differences, Treatment Differences. Jakarta: Spreader Plus.

[14] Sentanu, Erbe. (2002). Quantum Ikhlas, Technology of the Strength of the Heart Activity, The Power of Positive Feeling. Jakarta: Elex media Komputindo.

[15] Setyobroto, S. (2001). Mental Training. Jakarta: Solo Printing

[16] Soedarsono. (2009). http://www.koleksiskripsi.com, Acces sed April 22, 2018).

[17] Sobur Alex (2003). General Psychology. Bandung: Loyal Reader.

[18] Sugiyono (2014). Qualitative and Quantitative Research Methods and R\&D. Bandung: Alfabeta.

[19] Sudijono, Anas. (2000). Introduction to Research Statistics. Jakarta: PT. Raja Grafindo.

[20] Suryabrata. (2003). Personality Psychology. Jakarta: Raja grafindoPersada.

[21] Reading angle. (2017). ( https://www.sudutbaca.com /perp res-nomor-87tahun-2017-about-trengthening-character-ppk/ Accessed October 2, 2018)

[22] Syafruddin. (1994). Introduction to Practicing Science. Padang: FPOK IKIP Padang.

[23] Syafruddin. (2011). Sports Coaching. Padang: UNP Press.

[24] National Sports System Law No 3. (2005). Development and Development of Achievement Sports Article 27 Paragraph 4. Jakarta: PT SinarGrafika. 